\title{
PROFESSOR EDMUND GUSSMANN
}

\section{$1945-2010$}

In my welcoming remarks at the Fourth International Colloquium of Societas Celto-Slavica in Łódź, Poland, on the $13^{\text {th }}$ September 2009, I recalled that it was exactly forty years since I first met Edmund Gussmann when we were young postgraduate students studying Icelandic at the University of Iceland in Reykjavik. His untimely death at the young age of sixty-five on $2^{\text {nd }}$ September 2010 came as a great shock to both myself and all those who knew him well.

Following his Masters degree in English at the University of Warsaw in 1968, he won an Icelandic government scholarship in 1969 to study Icelandic language and literature in Reykjavik. It was during his time that he first developed an interest in Irish and in the Celtic languages. The period in Iceland was to have a profound influence on him both culturally and academically; he was deeply impressed by the country, its people, its language and culture. He also became a regular visitor to the island throughout the remainder of his life, particularly in his last ten years.

Edmund completed his doctorate in 1973 and his habilitation in 1978 on English linguistics. He also spent a period on a Fulbright Scholarship at MIT, where he studied under Chomsky, Halle and other renowned generative theoretical linguists. His Studies in Abstract Phonology, which was published by MIT Press in 1980, established his international reputation in the field of theoretical linguistics, with particular reference to phonology. This publication had been preceded by his Contrastive PolishEnglish Consonantal Phonology (Warsaw 1978); other major works followed, such as Phonology: Analysis and Theory (Cambridge 2002) and The Phonology of Polish (Oxford 2007). Edited works included Licensing in Syntax and Phonology (Lublin 1995) and Rules and the Lexicon: Studies in Word-formation (Lublin 1987).

His appointment as University professor at the Catholic University of Lublin in 1981 (full professor in 1985 and Ordinarius 1992) proved to be an inspired choice with regard to future developments in Celtic linguistics in Poland. As Professor in the newly-formed English department, he succeeded in appointing a Welsh language teacher, thereby kick-starting his Celtic linguistics programme. Having spent a year in Ireland at University College, Dublin, working in Professor Conn Ó Cléirigh's Department of Linguistics, he received support from the Irish Department of Foreign 
Affairs and set about introducing the study of Modern Irish in the Lublin programme. An Irish language teacher/lecturer was appointed and Irish became a compulsory component of the course. In 1991, he established the Chair of Celtic Studies at the Catholic University, a position which he himself occupied until he left Lublin in 1999. Some of his publications during this period were co-authored with the Irish linguist Aidan Doyle and included An Ghaeilge: podręcznik do nauki języka irlandzkiego (Lublin 1991/97) and A Reverse Dictionary of Modern Irish (Lublin 1996/2004).

Edmund returned to his first love of Icelandic when he took up the Chair of Icelandic in the School of Scandinavian Studies at Adam Mickiewicz University in Poznań, having previously spent some time as professor at the University of Gdańsk in the Institute of English Studies when he left Lublin in 1999.

With regard to contacts between the Celtic and Slavic cultures, he will be particularly remembered for introducing Celtic Studies as a discipline at the Catholic University of Lublin and ensuring the teaching of Modern Irish and Welsh to his students, establishing the Chair of Celtic Linguistics which continues to the present day to be an important force in both Celtic and General Linguistics, and his theoretical work on Irish and Icelandic.

Not only did Edmund have a very distinguished academic career, he was also one of those special people who greatly influenced those with whom he came into close contact. I will finish by quoting some of his own words to me in 2005 when we corresponded with regard to our first colloquium of Celto-Slavica at Coleraine in 2005:

As you see, I keep changing and trying to get things moving. If I get this Icelandic idea underway, I will be able to pass away in peace after having launched both Celtic and Icelandic Studies in Poland.

Having lived to see his ideas come to fruition, may this remarkable man and scholar be granted that peace he so richly deserves.

Go ndéana Dia grásta ar a anam uasal!

Séamus Mac Mathúna

Professor Séamus Mac Mathúna

President

Societas Celto-Slavica 